The End of Intelligence 



\title{
The End of Intelligence
}

Espionage and State Power in the Information Age

\author{
David Tucker
}

Stanford Security Studies

An Imprint of Stanford University Press

Stanford, California 
Stanford University Press

Stanford, California

(C) 2014 by the Board of Trustees of the Leland Stanford Junior University. All rights reserved.

No part of this book may be reproduced or transmitted in any form or by any means, electronic or mechanical, including photocopying and recording, or in any information storage or retrieval system without the prior written permission of Stanford University Press.

Library of Congress Cataloging-in-Publication Data

Tucker, David, author

The end of intelligence : espionage and state power in the information age / David Tucker.

p. $\mathrm{cm}$.

Includes bibliographical references and index.

ISBN 978-0-8047-9042-o (cloth : alk. paper) -

ISBN 978-0-8047-9265-3 (pbk. : alk. paper)

1. Intelligence service. 2. Espionage. 3. Information societyPolitical aspects. 4. Information technology-Political aspects.

5. Power (Social sciences). I. Title.

JF1525.16T83 2014

$327.12-\mathrm{dc} 23$

2014010112

ISBN 978-0-8047-9269-1 (electronic)

Printed in the United States of America on acid-free, archival-quality paper. Typeset at Stanford University Press in 10/14 Minion. 
To Ellen, NAthAN, and SARAh for revealing the beauty in chance events 
